\title{
The Discursive Representation of Social Groups through Lexical Choices in Headlines: A Critical Discourse Analysis of Western and Arab Online Reporting on Gaza War Hanan Mohamed Ahmed Sharaf Eldin
}

\begin{abstract}
This study offers a critical analysis of the representation of Israelis and Palestinians in headlines of the selected articles from Cable News Network (CNN), New York Times (NYT), Al-Ahram Weekly Online and Al Jazeera English online (AJE) coverage of the 2008 War on Gaza (Appendix 1). This analysis examines the way language is used to represent social actors involved in this conflict, and attempts to reveal the way lexical choices are politically and ideologically employed to affect the ideological stance of the reader. Headline analysis will be guided by Fairclough's (2003) three - dimensional Critical Discourse analysis (CDA) framework, and van Leeuwen's (2008) Social Actor Approach. In order to have a better understanding of media manipulation of its readers, certain aspects of the headline need to be addressed by trying to answer some questions such as: Which words are chosen to appear in the headline and what is the purpose of such choices? How are social actors represented through lexical choices? This analysis aims to compare the representation of Israeli and Palestinian actors in selected headlines of the four websites under study to show how political and ideological orientations of media organizations are reflected in discourse and the ideological construction of social actors.
\end{abstract}

Key words: CDA, headline, identity, ideology, lexical choices.

\section{Introduction}

On the $27^{\text {th }}$ of December 2008 a new cycle of the IsraeliPalestinian conflict irrupted with Israeli air attacks followed by a massive ground offensive against Gaza, under the pretext that Israel is defending itself against Hamas rocket attacks. This episode of the IsraeliPalestinian conflict continued until the $18^{\text {th }}$ of January 2009 and became to be known as Operation Cast Lead or Gaza War. The violence of the attacks and the imbalance of power between the Israeli and Palestinian sides resulted in a very high rate of casualties among Palestinians, mostly civilians. According to the United Nations reports approximately 1,400 Palestinians were killed in comparison to 13 Israeli deaths (Goldstone, 2009). Such violence and the high rate of fatalities among Palestinians have raised international concerns and attracted national and international media coverage of the event. Since the conflict involves two groups with different political, ideological and ethnical inclination, its coverage may 
The Discursive Representation of Social Groups through Lexical Choices in Headlines: A Critical Discourse Analysis of Western and Arab Online Reporting on Gaza War

result in politically motivated and biased language use. Powerful groups, governments and news editors control news coverage to impose their own opinion and ideology (Richardson, 2007). This may distort the image of social actors and affect the way readers perceive them. For this reason, several researchers have been interested to investigate the news discourse of the Israeli-Palestinian conflict like, Philo and Berry (2004), Bazzi (2009), Richardson and Barkho (2009), and Wang (2017). These studies have adopted different approaches and methods to analyse the media coverage of the conflict and they have mostly concluded that the reporting was generally biased and tends to reflect the imbalance of power between the two conflicting parties. However, these studies have mainly focused on analysing British and American media outlets and little attention is given to Arab news sources.

The article aims to analyse lexical choices made to refer to and represent Palestinians and Israelis in selected headlines covering the conflict. The study adopts Fairclough's (2003) CDA approach and draws upon van Leeuwen's (2008) Representation of Social Actor as a method of analysis with the aim of revealing underlying ideologies and the use of power in representation of social actors. Fairclough (2003, p.27) explains that the relation between discourse and society is dialectical; therefore, it is important to examine the ideologies, opinions and representations the media is trying to propagate in society to uncover how social events affect the discursive use of language and how the discursive practices influence public opinion towards conflicting groups.

\section{Critical Discourse Analysis}

Critical Discourse Analysis (CDA) aims to clarify ideological relations of power which underlie discourse and reflect the interaction between language, society and culture. Although CDA is concerned with the analysis of 'texts and interactions'; this is not where it begins. "It starts rather from social issues and problems, problems which face people in their social lives, issues which are taken up within sociology, political sciences and/or cultural studies" (Fairclough, 2001:26). What CDA attempts to prove, is that discourse is socially constitutive and at the same time it is socially conditioned. Hence, the role of CDA is perceived as "the uncovering of implicit ideologies in texts. It unveils the underlying ideological prejudices and therefore the exercise of power in texts" (Widdoson 2000: 157). Discourse does not stop at the grammatical aspects of language, but it goes deeper into the more complex relations between language, ideology and social interaction. Consequently, discourse can set the system of beliefs and values endorsed by an 


\section{Hanan Mohamed Ahmed Sharaf Eldin}

individual or a society to provide explanation of social, cultural, and political situations going on in the world.

\subsection{Fairclough's approach to CDA.}

Fairclough's framework has been central to CDA studies, and is considered one of the most comprehensive frameworks of CDA. Fairclough's approach of CDA, emphasizes three key elements that should be considered when analyzing a communicative event: "text", "discourse practice", and "sociocultural practice" (Fairclough, 2003, p. 57). "Text" is defined as "the written or spoken language produced in a discursive event" (Fairclough, 1993: 138). Discourse on the other hand, is the socially determined use of language. Hence, the relation between language and society as a "dialectical" relationship. (Fairclough, 1989, pp.22-3). Referring to discourse as a social practice indicates that discourse constitutes situations, elements of knowledge, power relations and identities of people, and at the same time it is shaped by social, historical and political events. Fairclough (1995a) relies on Halliday's SFL to examine text from a multifunctional perspective, trying to identify and clarify the ideational, interpersonal and textual functions of language and discourse (p.57). The text articulates certain representations, reflects ideologies and re-contextualizes social practices. Furthermore, the text expresses a certain relation between the writer and reader.

\subsection{Fairclough's contributions to media studies}

Media discourse has attracted Fairclough's attention for its salient effect on a vast audience. Fairclough (1995b) argues that the importance of studying media discourse goes back to central role of mass media in today's world. He added that by analyzing the language of media the researchers may offer insightful explanations for 'sociocultural' changes (Fairclough, 1995b, p. 3). News reports can act as a powerful persuasive tool to direct public opinion through the messages they select to communicate to their audience. However, the wider impact of the media texts does not only rely on "how they selectively represent the world", but equally on "what sorts of social identities, what versions of 'self', they project and what cultural values these entail" (Fairclough, 1995b, p. 17). Accordingly, the media convey messages to their audience dispatching individual values, norms, beliefs and codes of behavior. Fairclough expresses a particular interest in media discourse analysis as it can reveal power relations, representations, and identities. He believes that news text analysis can demonstrate how subjective media representations can be and how far they are influenced by the political and social conditions (Fairclough, 1989, p. 3-5). Therefore, news reports may offer different explanations and arguments concerning the same incident; moreover, they 
The Discursive Representation of Social Groups through Lexical Choices in Headlines: A

Critical Discourse Analysis of Western and Arab Online Reporting on Gaza War

are used by the readers/audience to form their own arguments and ideologies especially as regards conflicting groups.

This complies with Fairclough's (2003, p. 124) idea that discourses do not simply "represent the world as it is", but "they are also projective, imaginaries, representing possible worlds which are different from the actual world, and tied in to projects to change the world in particular directions." When a certain group is represented in the media, as the Palestinians or Israelis in the present research, a certain image of this group is developed asserting its social and political identity and driving the audience to adopt certain ideological stances towards such a group. Fairclough (2003, p. 27) fears that these representations may be "framed" to draw a certain image for one of the groups. The projected image in the media text may or may not comply with the true identity of the group involved depending on how reporters or the media institutions publishing the report wants to frame these conflicting groups by lexical choices and vocabulary used to refer to members of these groups. Fairclough (2003, p.145) and van Leeuwen (2008, p.32) agree that representation of social actors is realized through their grammatical role in the clause and through more complex socio-semantic categories as well. In order to get a profound understanding of the representation of social actors when they are included in a text, it is important to examine whether they are personalized or objectified, nominated or classified, and genericized or specified. Therefore, this article examines selected categories incorporated in van Leeuwen's (2008) socio-semantic inventory while examining the lexical choices made to represent Israeli and Palestinian actors in the selected headlines.

\subsection{Van Leeuwen's Tools for Critically Analyzing Social Actors}

Van Leeuwen (2008) provides CDA researchers with practical tools and analytical categories that can be used for the critical analysis of language usage within multidisciplinary frameworks. Van Leeuwen's (2008) CDA model is based on the notion that discourse is a recontextualization of social practice (p.5). His framework investigates the way social practices are discursively represented and transformed in the use of language and other semiotic means. In the process of recontextualization participants may be included or excluded, their roles may be foregrounded or backgrounded and their actions legitimized or delegitimized. Van Leeuwen's (2008) socio-semantic inventory includes the following categories for ideologically realizing social actors: genericisation and specification, assimilation, association and dissociation, indetermination and differentiation, nomination and 


\section{Hanan Mohamed Ahmed Sharaf Eldin}

categorization, personalization and impersonalization, functionalization and identification, and overdetermination. Fairclough (2003, p.155) points out that these representation choices are "socially significant". Therefore, van Leeuwen's (2008) socio-semantic inventory can be used to analyze the representation of social actors sociologically and critically before studying how they are realized linguistically.

\section{The Role and Importance of Headlines in News Reporting}

The choice of headlines is a key aspect in news reporting. A headline is the first element of the news report that the reader's sight falls upon and for many readers browsing the headlines may be the only part of the news story they would ever read. For this reason, van Dijk (1985, 1988, 1995) conceived the headline as the most significant element of a news story as it plays a focal cognitive and ideological function which can influence readers' interpretations and ideological stances. Headlines sum up the highlights of an intricate news story to grab the readers' attention and invite them to read further (Schneider, 2000, p.48). Clearly, headlines draw attention to the most prominent aspect of the story while deemphasizing other aspects; this is done by including or deleting information from the headline. Together with leads headlines represent the topic or theme of the news story "and express the semantic macrostructure" (Van Dijk, 1988, p. 53). This macrostructure is the most remembered part of the news story. However, headlines may have other functions as well, not just summarizing a story. Editors may use headlines to foreground or highlight a certain aspect or detail; moreover, they may include information which may not appear in the body of the article.

Headlines are powerful structures that point to the reader the central aspects of the story and places the event within the social order. Their powerful impact may be due to their lexical density and briefness that create a strong emotional impact (White, 1997, p.7). Online headlines are even more powerful as they may encourage readers to go and read the news story or not (Saxena, 2004, p. 43). Headlines appear following one another on webpages, browsers or mobile phone alerts and a reader may choose to scan through the headlines alone to get a glimpse of what events are going around in the world without even having to read the whole news story. Headlines then become the only source of information on a certain event. Saxena (2004) argues that online headlines have invited a new genre of headlines namely "descriptive headlines" that are abundant with description, information and even comments (p. 43). The choice of certain lexical items as adjectives, adverbs, nouns and verbs to describe the event and social actors involved in it may risk the objectivity of the news editors. The use of emotionally charged semantic and lexicogrammatical items allows the news editor to create an interpersonal 
The Discursive Representation of Social Groups through Lexical Choices in Headlines: A Critical Discourse Analysis of Western and Arab Online Reporting on Gaza War

relation with the reader, but at the same time breaches the neutrality of hard news (White, 1997, p. 5-7). For this reason, the present study examines emotionally loaded lexical choices together with the sociosemantic classification of social actors to reach a comprehensive understanding of the representation of Israeli and Palestinian actors and reveal the ideological stance of the four selected websites towards them.

\section{Method of Analysis}

\subsection{Selected Data}

Since the present study aims at investigating the representation of the Palestinian and Israeli actors in the Arab and western media, a corpus of news reports is selected from four websites: two of them represent Arab sources, namely Al Ahram Weekly Online and Al Jazeera English Online (AJE), and two other websites represent western sources, namely Cable News Network (CNN), and New York Times (NYT). All the collected articles are published in English on the four selected websites. Google search engine as well as the search options on the websites were used to locate the articles. All the articles were covering the Israeli offensive against Gaza, entitled Operation Cast Lead, from $27^{\text {th }}$ December 2008 to $18^{\text {th }}$ January 2009 (Appendix I). The key words used to search for the articles were:

Gaza, Cast Lead, offensive against Gaza, Gaza war, Israeli offensive, Palestinian - Israeli conflict, Israeli attacks, and attacks in Gaza.

The corpus includes nineteen articles from Al-Ahram Weekly Online, forty-nine articles from $A J E$, thirty-eight articles from $C N N$, and forty-two articles from NYT; that accounts for the total number of hard news articles published online to report this operation on the four websites (Table 4.1). Al-Ahram Weekly Online accounts for the least number of articles among the four websites chosen for this corpus since it is the only weekly publication among them. Al-Ahram Weekly Online and $A J E$ use multiple deck headlines, while $C N N$ and $N Y T$ use single deck headlines. On Al-Ahram Weekly Online pages headlines are followed by a summary, $A J E$ editors place a sub-heading including more details under the headline of the article, while $C N N$ and $N Y T$ use a one-line headline. 


\section{Table 3.1.}

Number and structure of Headlines of News Stories in the Selected Newspapers

\begin{tabular}{|c|c|c|c|c|}
\hline Website & & $\begin{array}{ll}\text { No. of } \\
\text { Headlines }\end{array}$ & Headline Format & $\begin{array}{l}\text { Publication } \\
\text { frequency }\end{array}$ \\
\hline $\begin{array}{l}\text { Al-Ahram } \\
\text { Online }\end{array}$ & Weekly & 19 & Headline and summary & Weekly \\
\hline$A J E$ & & 49 & $\begin{array}{l}\text { Headline and sub- } \\
\text { heading }\end{array}$ & Daily \\
\hline CNN & & 38 & One-line headline & Daily \\
\hline$N Y T$ & & 42 & One-line headline & Daily \\
\hline Total & & 148 & & \\
\hline
\end{tabular}

Hard news articles are selected on the basis of including direct coverage of the event, and excluding any other articles that express opinion or provide political commentary. Online news stories are selected for their vast outreach, and ease of access. Finally, the four websites under study are chosen for their high reputation in their countries and their wide circulation internationally. Moreover, Egypt, Qatar and the US are key players in the Israeli-Palestinian negotiations, therefore, it is interesting to examine how the political and ideological orientations of their governments influence the discursive practices involved in producing the news reports and representing Israeli and Palestinian actors.

\subsection{Procedure of Analysis}

To reach a better understanding of the way the social actors involved in the Israeli-Palestinian conflict are represented in media texts and the power relations these texts are reflecting, present study adopts primarily a CDA approach to analysing lexicalization in selected news headlines. The analysis is guided by Fairclough's (2003) dialectical relational CDA approach.

Fairclough identifies three distinctive aspects of discourse in the social world; discourse contributes to the constitution of social identities, social relationships, and systems of knowledge and beliefs. Discourse is shaped by social practices and can be reshaped by them (Fairclough, 2003, p, 126). This dialectical relation between discourse and society implies that particular discourses are formed in ways which are appropriate to the interests of positively or negatively representing social actors in given social contexts. 
The Discursive Representation of Social Groups through Lexical Choices in Headlines: A Critical Discourse Analysis of Western and Arab Online Reporting on Gaza War

In light of Fairclough (2003) notion of discourse, this study focuses on analysing specific lexical and vocabulary patterns as sensitive indicators of socio-political relations and representations of social actors. The analysis of lexis examines the representation of different groups of the conflict, how they are categorized and the choice of descriptions used with these groups and their actions attaining to their positive or negative evaluation, legitimization or delegitimization.

Drawing on this understanding of CDA, this study incorporates selected categories of van Leeuween's (2008) socio-semantic inventory as a tool of investigating the semantic representation of Israeli and Palestinian actors. Van Leeuwen's (2008) framework is useful in articulating the role of social actors in the text by drawing socio-semantic categories rather than grammatical categories. The analysis looks into how social actors are categorized when included in the texts through genericization and specification, individualization and assimilatio, nomination and categorisation, functionalization and identification in addition to personalization and impersonalization.

If social actors are genericized they are realized as groups or classes. When social actors are specified they are realized as real individuals that can be part of one's real world (van Leeuwen, 2008, pp.35-8).

Social actors can be referred to either as specified individuals or through assimilations describing them as groups. Individuality place the main emphasis on the social actors as single entities. Assimilations relate social actors to their social groups and create a sense of "conformity" with members of the same group (van Leeuwen, 2008, pp.37-8). Assimilations may also play a role in propagating stereotypes.

Nomination is realized by proper nouns and categorization occurs when social actors are referred to, based on their function or identities they share with other. (van Leeuwen, 2008, pp. 40-3). Identification is realized by classification, including ethnic, gender, age and religious classifications, relational identification and personal identification. Examining nomination and categorization strategies allows reserachers to acknowledge social actors who are individualized and humanized, and those who are positively or negatively evaluated.

Personalization takes place when social actors are realized as humans presented by personal or possessive pronouns, proper names or nouns. However, social actors can also be impersonalized when they are described by abstract nouns or concrete nouns that do not have the semantic property "human" (van Leeuwen, 2008, p.46). Impersonalization is realized by "abstraction" or "objectivation". 


\section{Hanan Mohamed Ahmed Sharaf Eldin}

Abstraction assigns abstract nouns that lack a human feature to actors. Objectivation occurs when social actors are substituted by metonymical references. Impersonalization intend to "background the identity and/or role of social actors; it can lend impersonal authority or force to an action or quality of a social actor; and it can add positive or negative connotations to an action or utterance of a social actor" (van Leeuwen, 2008, p.47).

In addition to these categories, the analysis of lexical choices in headlines examines the expressive value of nouns, adjectives, and verbs used to describe the actions of social actors or comment on them. Examining the expressive value of words reveals "the producer's evaluation (in the widest sense) of the bit of the reality it relates to" Fairclough (1989, p. 112). Analysis of the expressive value allows the discourse analyst to reveal social identities and easily realize the ideological significances in the written reports.

\section{Lexical Analysis- Representation of Israeli and Palestinian Actors in the Selected Headlines}

In order to proceed with the analysis of labelling of actors, the social groups included in the headlines of the four websites under study are first categorized according to their nationality; i.e. Israelis and Palestinians. Then each group is divided into sub-groups according to their role in the conflict. Table (5.3) shows the proposed division of subgroups.

Table 4.1

Division of groups and sub-groups in headlines

\begin{tabular}{|l|l|l|}
\hline Role & Israelis & Palestinians \\
\hline Military & Israeli Military Actors & $\begin{array}{l}\text { Palestinian } \\
\text { Actors }\end{array}$ \\
\hline $\begin{array}{l}\text { Political } \\
\text { leadership }\end{array}$ & Israeli Political Actors & Palestinian Political Actors \\
\hline Civilians & Israeli Civilians & Palestinian Civilians \\
\hline
\end{tabular}

\subsection{Israeli Military Actors.}

In the corpus of the headlines of the four websites under study, Israeli Military Actors are genericized and are not referred to as identifiable individuals. Genericization is realized through the mass noun 'Israel'; plural forms without articles 'Israeli troops', 'Israeli forces' 'soldiers', 'Israeli jets', 'Israeli missiles', 'Israeli raids', 'attacks'; indefinite article with a singular noun 'a captured Israeli soldier' and third person singular pronoun ' $I t$ '.

Israeli Military Actors are also functionalized as 'Israeli troops', 'Israeli forces', 'Israeli ground forces' and 'soldiers', in the examined 
The Discursive Representation of Social Groups through Lexical Choices in Headlines: A Critical Discourse Analysis of Western and Arab Online Reporting on Gaza War

headlines of $A J E, C N N$ and $N Y T$ headlines. In this case they are collectivized and categorized by occupation. Such representation aims to show the Israeli Military Actors as a consensual and homogenous group and emphasizes their strength and power. The choice of words such as 'troops' and 'forces' frames the Israeli military as an organized officially recognized force not just a group of 'fighters' as the Palestinians.

The power of the Israeli Military Actors is further clarified as they are impersonalised, in the corpus of headlines collected from the four websites, through instrumentalization as:

'Israeli jets', 'armoured convoy', and 'Israeli missiles' and abstraction as:

'Israeli attacks', 'airstrikes', 'invasion', 'Israeli raids', 'Israel's airstrikes', 'Israeli offensive', 'its aerial bombardment', 'onslaught', 'war' and 'campaign'

These impersonalized lexical choices replace Israeli agents in headlines. The impersonalization of Israeli Military Actors serves to mystify the identity of the agent and at the same time frame Israel as a powerful State possessing a mighty military arsenal. Such impersonalization drives readers to comprehend the full power of Israel as seen in its forces, military machine, and military operations. It also helps mitigate responsibility of any particular human actor.

Each website has chosen between a variety of nouns and adjectives to refer to the Israeli attacks on Gaza. AJE special media coverage came under the title of War on Gaza transforming the incident from a mere episode in the ongoing Israeli-Palestinian conflict into a full-fledged war. Mainly, the Arab websites, Al Ahram Weekly Online and AJE, tend to opt for more powerful emotionally loaded lexical items to describe the Israeli attacks examples from the corpus Al Ahram Weekly Online include:

carnage, brutal war, invasion, bloody aerial assault, flagrant Israeli war crimes, 'Crime of crimes', overwhelming onslaught.

In the examined corpus, $A J E$ also uses emotionally loaded lexis in connection with Israel's military actions as in the following examples:

deadliest attack, all-out war, ground offensive, ground assault, invasion, fighting rages, deadly Gaza attacks, air raids intensify, genocide, intense attack, intensive sea and air strikes, continuing assault,

These nominalizations and adjectives help the reader visualize the bloodiness and brutality of the situation on the ground. In Al Ahram Weekly and $A J E$ headlines the war is described through the use of negative adjectives, which are rarely used by the western websites, as 


\section{Hanan Mohamed Ahmed Sharaf Eldin}

flagrant, all-out-war, brutal, non-stop and crime of all crimes, as for the attacks they are further illustrated by adjectives such as bloody, deadliest, overwhelming, intensive and intense. Al Ahram Weekly Online plainly calls the Israeli attacks an 'invasion' and AJE refers to Israel as 'the occupation'. These lexical choices saliently reflect Al Ahram Weekly Online and $A J E$ aim to delegitimize Israeli actions and show Israeli Military Actors as unjustifiably using violence against Palestinians.

On the other hand, in selected data from Western websites, $C N N$ writers used lexical choices such as clash, crossfire and conflict to show its readers that Israel is involved in military action with its opponent in this case Hamas. CNN and NYT also used nouns as incursion and battle bringing to the reader's mind that it is a short and brief attack for a specific purpose. In addition, adjectives used by $C N N$ and $N Y T$, in the examined corpus, include stepped up and broadening which do not connote violence or bloodiness as much as they just insinuate a wider scope for the operations. Even when all-out war is used, it is placed between parentheses to detach it from being the stance of the website.

Thus, $C N N$ and NYT hold both Israel and the Hamas equally responsible for the eruption of violence and create a sense of balance between the two powers. However, this is not the true situation as Israel has a formal army facing most of the time unarmed civilians, as confirmed by the UN reports (Goldstone, 2009). The lexis CNN and NYT use to describe of the military actions by Israelis while still showing Israel as a powerful military power, it implies that Israel is not an instigator of violence, it resorts to violence only when it is involved in a clash with Hamas and for a short period of time. NYT even goes to attracting sympathy to Israeli soldiers through the use of adjectives as in the headlines:

A captured Israeli soldier figures in military assessments and political calculus

Israelis honor fallen soldiers

The choice of the emotionally loaded words 'captured' and 'fallen' to describe Israeli soldiers shows their vulnerability and adds to the legitimacy of Israel in defending itself against Hamas.

The overall representation of Israeli Military Actors, in the four websites, serves an ideological purpose of representing the power and hegemony of Israel in this conflict. The representation aims at reflecting the military power and supremacy of the Israeli actors, Israel's ability to instigate action by virtue of its military capacity. However, the Arab websites differ from the western websites in perceiving Israel's military actions as legitimate or justifiable. 
The Discursive Representation of Social Groups through Lexical Choices in Headlines: A Critical Discourse Analysis of Western and Arab Online Reporting on Gaza War

\subsection{Palestinian Resistance Actors.}

The only actors that engage in the fighting with the Israeli forces in this conflict is Hamas and its fighters. Hamas is also the group negotiating a ceasefire with Israel. Hamas also has a sort of political capacity as some of its members hold ministerial positions in the Palestinian cabinet. However, the representation of Hamas in the headlines of the four websites examined in this study aims to set Hamas apart from Palestinian Political Actors and Palestinian Civilian Actors for different ideological purposes.

The Palestinian Resistance is mainly genericized by a mass noun 'Hamas', plural forms without articles 'Hamas leaders', 'Palestinian fighters', 'Hamas figures' 'Hamas rockets', and 'Hamas mortars; and third person singular pronoun ' $I t$ '. Hamas genericization aims to represent the Palestinian Resistance as one homogenous group united together for the same purpose. This generic reference to Hamas in Al-Ahram Weekly Online, AJE, CNN, and NYT also aims to set Hamas apart from the Palestinian civilians and the Fatah led government. Moreover, by generically referring to Hamas, AJE, CNN, and NYT emphasize to their readers that Israeli military action is targeting Hamas and not the Palestinian civilians; although each website has a different ideological stance the drives such a representation. While $A J E$ wants to direct its audience attention to Hamas capability to stand against Israeli military and defend the Palestinians, $C N N$ and $N Y T$ have a different objective. $C N N$ and $N Y T$ use Hamas as a pretext for the Israeli military operations and justify the violence enacted by the Israeli forces.

In this context, functionalization and personalization play an important role in reflecting the websites ideological stance towards Hamas. AJE refers to Hamas members as 'fighters' framing them positively as the actors who are defending their land and people against an aggressor. In the Arab culture the term 'fighter' may carry some religious implications as well. AJE wants to represent Hamas to its readers as a group that does not submit to defeat easily and defends its rights. The term carries more positive connotations when it is modified by the adjective 'Palestinian' classifying them by nationality to the Palestinian people and identifying them as belonging to the wider community of Palestinians.

Moreover, elite members of Hamas are functionalized and personalized as 'leader' and 'commander'. In $A J E$ headlines Hamas elite members are mostly specified and individualized by a singular noun without an article. Hamas elite members are referred to as 'Group's field 


\section{Hanan Mohamed Ahmed Sharaf Eldin}

commander', 'Hamas leader', 'Political leader of Hamas', 'senior Hamas leader', and 'senior leader'. Hamas actors are thus humanized to further emphasize their positive image to readers of the website and bring them closer to the reader. Modifications are added to stress their affiliation to the group (Hamas), military and political capacity (field, political) and high rank (senior). Moreover, this representation by $A J E$ has an ideological purpose of framing Hamas members as official leaders adding to $A J E$ legitimization of the group and its actions.

$C N N$ and $N Y T$, rarely functionalize Hamas or specify its members. Both websites aim to dehumanize Hamas and detach it from its readers. Similarly does Al-Ahram Weekly Online, by referring only generically to the group in its headlines as 'Hamas' or 'it'. CNN specifies members of Hamas in the headlines when they are targeted by Israel as in '2 top Hamas figures' and ' 1 killed'. This aims to show $C N N$ readers that the purpose of the Israeli operations is targeting Hamas and not the Palestinian people.

$A J E, C N N$ and $N Y T$ are also interested in making lexical choices that reflect the military power of Hamas. In AJE, CNN and NYT headlines, Hamas is objectified as 'Hamas rockets', 'Hamas mortars' and 'upgraded rocket arsenal', and abstracted as 'rocket attacks'. Moreover, Hamas is also abstracted as 'resistance' and 'Hamas rule'. Again, such references aim to show that Hamas has some sort of power to stand against Israel and carry military action.

Thus, the general image of the Palestinian Resistance in the four websites under study is framed in Hamas as a group separate from the Palestinian people and has the capacity to possess military equipment and fight against Israel. The ideological purpose of such representation differs from one website to the other based on the political stance of its affiliated government.

In Al-Ahram Weekly Online this representation reflects Egypt's denouncement of Hamas actions seeing the Group as provoking Israel and instigating its attacks against Palestinians. When Operation Cast Lead was launched against Gaza, several Arab countries, primarily Egypt, blamed Hamas for taking unwise and uncalculated actions to provoke Israel. These states took such a stance as they were siding with Mahmoud Abbas as the legitimate Palestinian Authority, and declaring their opposition to Hamas' close relation with Iran (Migdal, 2014, pp. 252-4). As seen from the collected Al Ahram Weekly Online headlines, Hamas is Fiddling while Gaza burns, in reference to the irresponsible attitude of Palestinian factions who are pre-occupied by their own disputes rather than focusing on the Palestinian - Israeli conflict. Al Ahram Weekly Online also refers to Hamas unwise actions through this headline 
The Discursive Representation of Social Groups through Lexical Choices in Headlines: A Critical Discourse Analysis of Western and Arab Online Reporting on Gaza War

Spoiling for a fight, and stating that Hamas provoked Israel. Such lexical choices represent Hamas as an irrational and irresponsible group that does not calculate the consequences of its actions on the Palestinian people in Gaza. This image of Hamas makes it difficult for readers to sympathize or side with Hamas during this particular period of the Israeli-Palestinian conflict.

$A J E$ representation of Hamas in the selected headlines reflects its support for Hamas and presents it as capable of defending Palestinians and challenging Israel. There is seldom a headline attacking Hamas except when the US Blames Hamas 'THUGS'. Although the noun 'thugs' stirs all the negative meanings of an illegitimate, criminal, immoral group, still $A J E$ detach itself from being responsible of such description by attributing it to the US and not even identifying who exactly says so. Thus, $A J E$ remains consistent with its representation of Hamas as playing a vital role in defending the Palestinian land and people. AJE represents Hamas as a patriotic group ready to sacrifice its members for the sake of its people as in the headline Hamas calls for third Intifada and the subheading Political leader of Hamas says "resistance will continue through suicide missions". Given the Islamist background of Hamas 'resistance' and 'suicide missions' are plausible acts when committed for the sake of defending one's country and people.

$C N N$ and NYT on the other hand, representation of Hamas in the collected data reflects the US and Israeli opposition towards Hamas and aims to help their readers find justification for Israel's actions aimed to stop 'Hamas rockets'. This is reflected in CNN headlines as:

Olmert: No peace in Gaza till Hamas rockets stop

Bush blames Hamas for Gaza conflict

Olmert: Attack on Gaza was 'unavoidable'

Israel, U.S. target Hamas arms smuggling

Israel: Hamas mortars prompted attack near U.N. school

Moreover, examples from NYT headlines include:

Foreign Minister of Israel says Hamas should be condemned

Despite strikes, Israelis vow to soldier on

These headlines negatively frame Hamas as an instigator of violence and Hamas is delegitimized for using arms smuggling. Moreover, the headlines show the U.S. and Israeli stances towards Hamas, as it should be 'blamed' and 'condemned' and 'targeted' for its actions. At the same time, this allows the readers to see Israeli actions in response to Hamas as legitimized. 


\section{Hanan Mohamed Ahmed Sharaf Eldin}

In the selected headlines under study, $C N N$ and $N Y T$ make lexical choices that negatively represent Hamas and reflect its determination to continue the fight. In the analysed corpus, $C N N$ headlines focus on Hamas rejection of any peaceful solution and that it will always continue to fight Israel. Therefore, in the headline 'Hamas promises a fight to the death' the reporting verb 'promises' is chosen to imply Hamas determination to fight Israel as long as it takes. The NYT follows the same line and shows Hamas as Striking Deep into Israel, and it Employs an Upgraded Rocket Arsenal. Hamas here is well armed as it is able to 'strike deep' and by adding the adjective 'upgraded' to describe its arsenal the editors implies that the military power of Hamas equals that of Israel. Moreover, in the NYT headline 'Israel declares cease-fire; Hamas says it will fight on', NYT reporter compares between the Israeli inclination towards peace and Hamas insistence on fighting. This representation of Hamas in $C N N$ and $N Y T$ as a defiant group seeking to engage in acts of violence ensures that readers will not sympathize with the group or see its actions as legitimate.

\subsection{Israeli Political Actors.}

Reference to Israeli Political Actors is almost limited in the headlines of the four websites. When Israeli Political Actors are included in the headlines they are mostly engaged in verbal processes to express the opinion of the Israeli government regarding justification of the operations or ceasefire. Being members of the elite in this context their official position is emphasized by mostly specifying and personalizing members of this sub-group.

In the examined corpus of news headlines from the four websites, Israeli Political Actors are nominated formally in AJE 'Livni' and CNN 'Olmert'. They are also nominated by their unique position as 'Foreign Minister' in AJE and 'Foreign Minister of Israel' in NYT. According to van Leeuwen (2008), nomination may be realized if a single social actor performs a certain function or occupation (p.41). Other references to Israeli Political Actors in the corpus of AJE CNN and NYT headlines include their institutionalization as 'Israel', 'Israeli Cabinet', and spatialization as 'Tel Aviv' the seat of the Israeli government.

As for Al-Ahram Weekly Online the headlines excluded any specific reference to Israeli Political Actors, as the editorial strategy gives more attention to the military operations and the suffering of the Palestinian civilians.

The overall image of the Israeli Political Actors is that of government actors and official leaders entitled to convey the opinion and determination of the State of Israel. 
The Discursive Representation of Social Groups through Lexical Choices in Headlines: A Critical Discourse Analysis of Western and Arab Online Reporting on Gaza War

\subsection{Palestinian Political Actors.}

This sub-group is mainly represented in Al-Ahram Weekly Online in the Palestinian President Abbas and his Ramallah emergency government. The Weekly nominated the Palestinian Political Actors officially as 'Abbas', classified them as a group 'Fatah' and finally using the spatial reference 'Ramallah' as the administrative capital of the Palestinian National Authority (PNA). This representation by Al-Ahram Weekly Online aims to highlight the official image of Palestinian Political Actors and legitimize the status of Abbas caretaker government which was challenged by Hamas and its parliamentary majority bloc. However, the limited recurrence of this sub-group in the headlines and its lack of action other than 'silence' as in the sub-heading Ramallah's silence on Israel's campaign of slaughter in Gaza is turning back on Fatah with a vengeance and being 'in limbo' in the headline Abbas in limbo, still frames Palestinian Political Actors as a group that lacks power and standing helpless specially in the face of Hamas.

$A J E$ representation of Palestinian Political Actors focuses on Abbas and his attitude towards Hamas and attempt to plead for an end of the military operations. AJE specifies and formally nominate 'Abbas' by his last name and his official occupation 'President', 'Palestinian President', and 'Palestinian Leader'. However, AJE excludes any reference to Abbas emergency government or its members from the headlines and nominates instead Hamas member as 'Hamas Interior Minister' using Hamas as a modifier to stress that he is a member of its self-imposed government in Gaza. This representation of Abbas aims to show that AJE still respects him as an Arab and Palestinian leader, although his role is limited to blaming Hamas e.g. Abbas blames Hamas for bloodshed or pleads for a solution for the conflict as in the headline Abbas urges action on Gaza.

CNN radically excludes Palestinian Political Actors from their headlines and NYT generically refers to them as 'Palestinian leaders'. This reflects their editorial ideology that aims to propagate the war as mainly an action against Hamas and not the Palestinian legitimate authority nor the Palestinian people. Nevertheless, this representation or rather lack of representation indicates that the news editors of the two websites see Palestinian Political Actors as not newsworthy for their audience or as lacking power to express opinion or undertake action in this particular episode of the Israeli-Palestinian conflict.

\subsection{Israeli Civilian Actors}

Al Ahram Weekly Online editors radically exclude Israeli civilians from their headlines while $A J E, C N N$ and $N Y T$ offer a very limited 
representation for this sub-group. For the Arab websites it is clear that they do not want to attract sympathy to the Israeli civilians, to a far extent to avoid accusations by their Arab followers that they are siding with Israel. However, this biased attitude contradicts the values of objective reporting.

In $C N N$ and NYT analyzed corpus of headlines, editors of both websites aim to maintain the image of Israel as having the upper hand in this war and not suffering losses at the hand of Hamas. Therefore, they limit the representation of Israeli civilian victims in their headlines. CNN and NYT intend to maintain a positive presentation of Israel and gain the support of their readers for Israeli actions. Israeli civilians are represented as victims of crossfire in $C N N$ headlines and they are genericized by plural without article as 'civilians', and 'civilian casualties'. In NYT headlines, they are categorized by ethnicity as 'Israelis' to show their solidarity as a homogeneous group in situations when they 'vow to soldier on' or 'honor fallen soldier'.

\subsubsection{Palestinian Civilian Actors.}

The overall image of Palestinian civilians in the headlines of the present corpus, is that of victims of the war. In Al Ahram Weekly Online, Palestinian civilians are personalized to help readers identify with them. They are genericized with plurals without articles as 'Palestinians', 'children' 'friends' and 'families'. They are categorized and identified by ethnicity 'Palestinians' and 'Gazans', age 'Children' and relational identification as 'families'. These categorizations frame Palestinians as vulnerable members of the community that should be protected not 'targeted' come 'under fire' or get 'wounded'. This image will help readers to sympathize with the Palestinian civilians and feel their pain and suffering.

$A J E$ offers that most varied representation of Palestinian civilians. $A J E$ is mainly concerned with specifying Palestinian civilians through high numeric quantifiers and aggregation as in the following headlines and sub-headings :

Air assault targets security buildings killing at least 220 people and injuring 700 more

Gaza toll nears $\mathbf{3 0 0}$ amid new raids

Toll reaches 428 as Israel maintains its aerial bombardment of the Gaza Strip.

More than 300 children have been killed in Israel's continuing assault, UN says.

Israel kills dozens at Gaza school

Israeli shells hit UN school sheltering hundreds of civilians in Jabalya refugee camp. 
The Discursive Representation of Social Groups through Lexical Choices in Headlines: A

Critical Discourse Analysis of Western and Arab Online Reporting on Gaza War

Documented data allows readers to see news reporters as objective and creates trust between the reader and the media outlet. Furthermore, it helps readers visualize the magnitude of the military actions and the huge number of casualties these operations resulted in (van Leeuwen, 2009, p.37).

In $A J E$ headlines, Palestinian civilians are genericized by plurals and third-plural pronoun, and categorized and identified by ethnicity 'Gazans', 'Palestinians', and by age 'children'. Palestinians are functionalized as 'doctors' and 'patients'. Besides such personalization of Palestinian civilians, AJE employs impersonalized reference to Palestinian civilians to illustrate that Israel's military operations are extended beyond targeting people to the fundamental services necessary for their own survival and living. To fulfil this purpose $A J E$ refers to Palestinian civilians by objectivation as 'hospitals', 'lifeline tunnels', and 'Gaza school' instead of referring to them as children or residents for example. These objects are 'hit', and 'pound' by Israel. AJE generally aims to portray an image of Palestinian civilians as victims, killed in huge numbers in Israeli operations and even if they survive the attacks they will suffer a hard life with no sources to sustain them.

$C N N$ and NYT share the same representation of Palestinian civilians as victims with the Arab websites. In $C N N$ and NYT Palestinian civilians are genericized through the mass noun 'Arab clan'; plural forms without articles 'civilians, 'Palestinians' 'Gaza families', 'doctors, and 'witnesses. They are personalized and categorized by ethnicity 'Palestinians' and relational identification '2 daughters' and 'Gaza family' and 'Gaza families'. Palestinians are also specified by aggregation in $C N N$ and NYT but by fewer quantifiers than AJE as ' 30 civilians', ' 4 Palestinians', '375', and ' 3 daughters'. Only towards the end of the war $C N N$ and NYT reports the approximate number of Palestinian casualties at 1,300 in $C N N$ and 1,000 in NYT. Finally, Palestinian civilians are functionalized as 'doctors', and functionalized and specified by a singular noun without an article as 'doctor', 'Gazan doctor' and 'peace advocate'. Still in CNN and NYT the overall image of Palestinian civilians is that of victims that deserve sympathy, although the responsibility of their suffering is not always clear. Civilians are casually present in the battles as $C N N$ headline clarifies 'Civilians on both sides caught in crossfire' or NYT headline 'For Arab clan, days of agony in a cross-fire'. The use of the noun 'crossfire' to refer to the Israeli attacks lays the responsibility of the Palestinian Civilians suffering on Hamas as well as Israel. Moreover, Palestinian Civilians appear as commentators of their own suffering as in CNN headlines 'Gaza hospital crowded with civilians, doctors say', and 


\section{Hanan Mohamed Ahmed Sharaf Eldin}

'Palestinians: 1,300 killed, 22,000 buildings destroyed in Gaza' as well as NYT headline 'Gazan doctor and peace advocate loses 3 daughters to Israeli fire and asks why'. Thus, CNN and NYT represent Palestinian civilians as victims of this war that deserves sympathy; especially as Hamas is partly involved in their suffering.

\section{Conclusion}

This study attempted to highlight the value of lexical choices in constructing the representation of social actors, specially, in a situation of conflict. It also tried to reveal the way media producers can influence their readers to adopt a negative or a positive stance towards one group or the other. They study made use of Fairclough's (2003) dialectical relational CDA approach and van Leeuwen's (2008) socio-semantic features to demonstrate the lexical choices made to refer to Israeli and Palestinian groups are ideologically and politically motivated.

The examination of lexical choices and socio-semantic representation of social actors showed that there are certain similarities and differences among the four websites under study.

The four websites, Israel is represented as a powerful military authority. Israeli Military Actors are mostly genericized to reflect their solidarity and impersonalized to mitigate human responsibility of any violent action and highlight Israel's image as a powerful State. However, Arab websites, Al Ahram Weekly Online and AJE use emotive language to draw condemnation towards Israeli military operations and attract sympathy towards Palestinian civilian victims. Lexical choices in $C N N$ and $N Y T$, on the other hand, aimed to represent Israeli Military Actors not as initiators of violence, but as responding to Hamas rocket attacks.

The four websites showed similarity in representing Hamas as the main opponent to Israeli military. In this regard, Hamas is mostly genericized and classified as a unified group set apart from the other Palestinian political actors and Palestinian civilians. Hamas military capacity is emphasized by $A J E, C N N$, and $N Y T$, through objectivation and abstraction. However, there were also some differences in representing Hamas among the four websites.

Differences between the websites were also observed. AJE is the only website that aimed to represent Hamas positively and legitimize its members by specifying and individualizing Hamas members and reflecting an image of Hamas as a patriotic group defending the Palestinians. AJE lexicalization of Hamas aimed to draw readers' sympathy to the group. In contrast, lexical choices and nominalizations in Al Ahram Weekly Online represented Hamas as an irresponsible group provoking Israel. $C N N$ and $N Y T$, negatively represented Hamas as a group determined to continue fight and get engaged in illegitimate acts. 
The Discursive Representation of Social Groups through Lexical Choices in Headlines: A

Critical Discourse Analysis of Western and Arab Online Reporting on Gaza War

Moreover, $C N N$ and $N Y T$ showed Hamas as rejecting peace and ceasefire. Thus, in Al Ahram Weekly Online, CNN and NYT, Hamas is negatively represented and its actions delegitimized, a matter which draws readers away from sympathizing with Hamas or its members.

Across the four websites, Israeli and Palestinian Political Actors were specified and identified in their official political capacity. This shows that the websites have preferable treatment to elite members of the society and high-ranking officials. Israeli Political Actors were represented as representatives the government and official leaders authorized to convey the opinion and determination of the State of Israel.

Political Actors played a limited role in this conflict and editorial strategies focused more on representing Groups involved in the military operations and those affected by it. When included in the headlines, Israeli Political Actors were specified and identified in their official political capacity. Israeli Political Actors were framed as representatives the government and official leaders authorized to convey the opinion and determination of the State of Israel. Moreover, when Palestinian Political Actors were included in the selected headlines, they were also specified and identified. This shows that the websites have preferable treatment to elite members of the society and high-ranking officials.

Differences in the representation of the Israeli and Palestinian Political Actors among the Arab and western websites were also observed. In Al-Ahram Weekly Online headlines Israeli Political Actors were excluded, as the editorial strategy put more emphasis on military operations and the suffering of the Palestinian civilians. In contrast, Palestinian Political Actors were radically excluded from selected CNN headlines, while in NYT they were genericized as 'Palestinian leaders'. The analysis showed that editorial strategy of $C N N$ and $N Y T$ ideologically aimed to focus on Hamas as the main target of Israeli military actions and not the Palestinian legitimate authority nor the Palestinian people. At the same time, exclusion of Abbas and his government from the headlines of the two websites indicated that their news editors ideologically did not perceive them as newsworthy for their audience and framed Abbas and his government as lacking power to express opinion or undertake action concerning the fighting in Gaza.

The study also showed that Al-Ahram Weekly Online and AJE lexicalization of Palestinian Political Actors aimed to legitimize their roles; however, it also reflected the incapacity of Abbas in finding a solution for the conflict. Abbas and Hamas are represented as two political opponents, with Abbas blaming Hamas for the violence and rejecting its actions. 


\section{Hanan Mohamed Ahmed Sharaf Eldin}

The study found that the four websites recognized Palestinian Civilians as victims and their lexicalization draws sympathy to their vulnerable state. Palestinian Civilians were mostly personalized and genericized to attract the readers' sympathy and they were specified by numeric aggregation to present readers with actual data about the number of casualties. Al-Ahram Weekly Online and AJE used emotionally loaded lexis to victimize the Palestinians and draw the readers' sympathy towards them. Relational identification was also used to create a connection between readers and the victims. On the other hand, the radical and partial exclusion of Israeli Civilians was ideologically driven to maintain a powerful image of Israel and Israeli actors.

Finally, the present study highlights a number of remarks. First, CDA has proven to be a useful approach to compare the representation of Israeli and Palestinian groups in two major Arab websites and two powerful western websites, and analyse the lexical choices and representational categorize in the selected headlines. CDA helps reveal the ideological use of language to represent the parties involved in the conflict and their actions. Second, analysis of lexical choices helps reflect bias in news coverage, but more importantly it reveals how media institutions can manipulate their readers and lead them unconsciously to adopt certain political stances. Moreover, CDA helps prove that although media institutions and news producers claim to have the authority to inform people of the truth; however, their word choices reveal that their truth would vary as regards which party of the conflict they side with. 
The Discursive Representation of Social Groups through Lexical Choices in Headlines: A Critical Discourse Analysis of Western and Arab Online Reporting on Gaza War

\section{References}

Fairclough, N. 1989. Language and power. London: Longman.

Fairclough, N. (1993). Critical discourse analysis and the marketization of public discourse: the universities. Discourse \& Society, 4(2), 133-168.

Fairclough, N. (1995a). Critical discourse analysis: The critical study of language. London: Longman.

Fairclough, N. (1995b). Media discourse. London: Edward Arnold.

Fairclough, N. (2001). Critical discourse analysis. In A. McHoul, \& M. Rapleyeds (Eds.), How to analyze talk in institutional settings: A casebook of methods. (pp. 25-38). London: Continuum.

Fairclough, N. (2003). Analysing discourse: Textual analysis for social research. London: Routledge.

Goldstone, R. (2009, September 29). Report of the United Nations fact finding mission on the Gaza conflict: Executive summary. Retrieved from http://www2.ohchr.org/english/bodies/hrcouncil/docs/12session/AHRC-1248 ADVANCE1.pdf

Halliday, M. A. K. (2014). An introduction to functional grammar. $\left(4^{\text {th }}\right.$ edition.). London \& New York: Routledge.

Migdal, J. S. (2014). Shifting Sands: The United States in the Middle East. New York: Columbia University Press.

Philo, G., \& Berry, M. (2004). Bad news from Israel. Pluto Press.

Richardson, J. E. (2007). Analysing newspapers: An approach from critical discourse analysis. Houdmills: Palgrave Macmillan.

Richardson, J. E., \& Barkho, L. (2009). Reporting Israel/Palestine: Ethnographic

insights into the verbal and visual rhetoric of $\mathrm{BBC}$

journalism. Journalism

Studies, 10(5), 594-622.

Saxena, S. (2004). Breaking news: The craft and technology of online journalism.

Tata McGraw-Hill Education

Schneider, K. (2000). The Emergence and Development of Headlines in British Newspapers. Ungerer, F. (Ed.) English Media Texts Past and Present: language and textual structure 80, 45-66. Amsterdam: John Benjamins Publishing.

Van Dijk, T. A. (1985). Structures of news in the press. Discourse and communication: New approaches to the analysis of mass media discourse and communication, 10, 69 - 93.

van Dijk, T.A. (1988). News as Discourse. Hillsdale, NJ.: Lawrence Erlbaum Associates. Retrieved from http://www.discourses.org/OldBooks/Teun\%20A\%20van\%20Dijk\%20$\% 20 \mathrm{News} \% 20$ as \%20Discourse.pdf 


\section{Hanan Mohamed Ahmed Sharaf Eldin}

Van Dijk, T. A. (1995). Power and the news media. Political communication and action, 6(1), 9-36.

Van Leeuwen, T. (2008). Discourse and practice: New tools for critical discourse analysis. Oxford University Press.

Wang, C. (2017). Victimhood in the Face of Media Ideological Battle: A Critical

Discourse Analysis on the British Media's Coverage of Stabbing Incidents in the Israeli-Palestinian Conflict. Journal of Holy Land and Palestine Studies, 16(1), 79-98.

White, P. (1997). Death, disruption and the moral order: The narrative impulse in mass-media 'hard news' reporting. In F. Christie and J. R. Martin (Eds). Genre and institutions: Social processes in the workplace and school. (pp. 101-133). London: Cassell.

Widdowson,H.G. (2000). Critical practices on representation and the interpretation of text. In S. Sarangi, \& M. Coulthard (Eds.), Discourse and social life (pp. 155-169). Harlow: Pearson Education. 
The Discursive Representation of Social Groups through Lexical Choices in Headlines: A

Critical Discourse Analysis of Western and Arab Online Reporting on Gaza War

\section{Appendix 1}

\section{Headlines from the Four Selected Websites}

The appendix includes the data that was used for analysis. The headlines are presented in bold to separate them from subheadings. The articles are collected from $27^{\text {th }}$ December 2008 till $18^{\text {th }}$ January 2009 from the websites of, Al-Ahram Weekly Online and Al Jazeera, CNN, and New York Times, using the keywords: Gaza, Palestinian, Israeli, offensive, Gaza War.

\section{Articles retrieved from Al-Ahram Weekly Online}

Since Al-Ahram Weekly Online is a weekly publication it has the least number of articles among the four websites under study; however, it was particularly chosen for its renowned position in the Arab world and wide readership worldwide.

\begin{tabular}{|c|c|c|}
\hline \multicolumn{3}{|c|}{$\begin{array}{l}\text { Articles retrieved from } A l \text {-Ahram Weekly Online: } \text { http://weekly.ahram.org.eg/ } \\
\text { and https://www.masress.com/* }\end{array}$} \\
\hline No. & Date & Headline \\
\hline 1 & 2009, January 1 & $\begin{array}{l}\text { Fiddling while Gaza burns } \\
\text { What does it take to unite against the invasion, asks } \\
\text { Khaled Amayreh in Ramallah }\end{array}$ \\
\hline 2 & 2009, January 1 & $\begin{array}{l}\text { Is the world watching? } \\
\text { Without justification, Israel kills, writes Saleh Al- } \\
\text { Naami }\end{array}$ \\
\hline 3 & 2009, January 1 & $\begin{array}{l}\text { Palestine's Guernica } \\
\text { Mustafa Barghouti cuts down the myths Israel spins } \\
\text { in the media to justify its most recent campaign } \\
\text { of slaughter }\end{array}$ \\
\hline 4 & 2009, January 1 & $\begin{array}{l}\text { Spoiling for a fight } \\
\text { Hamas provoked Israel and received the response it } \\
\text { wished for, argues Emad Gad }\end{array}$ \\
\hline 5 & 2009, January 1 & $\begin{array}{l}\text { Raining death } \\
\text { Saleh Al-Naami reports from Gaza on the carnage } \\
\text { wreaked by five days of Israel's bloody aerial assault }\end{array}$ \\
\hline 6 & 2009, January 8 & $\begin{array}{l}\text { Assistance already delivered } \\
\text { The ghosts of Israel's war on Lebanon in } 2006 \text { hang } \\
\text { over Gaza's battlegrounds. Omayma Abdel-Latif writes } \\
\text { from Beirut on Hizbullah's options }\end{array}$ \\
\hline 7 & 2009, January 8 & $\begin{array}{l}\text { Children under fire } \\
\text { Aside from its direct killings, Israel's continued siege } \\
\text { on Gaza and the psychological trauma of its war } \\
\text { offensive are destroying life, especially children, writes } \\
\text { Saleh Al-Naami }\end{array}$ \\
\hline 8 & 2009, January 8 & $\begin{array}{l}\text { No going back now } \\
\text { Israel may be seeking to destroy Hamas, but what it is } \\
\text { actually doing is destroying any possibility for peace, } \\
\text { writes Khaled Amayreh in Ramallah }\end{array}$ \\
\hline
\end{tabular}




\begin{tabular}{|c|c|c|}
\hline \multicolumn{3}{|c|}{ Hanan Mohamed Ahmed Sharaf Eldin } \\
\hline & 2009, January 8 & $\begin{array}{l}\text { Searching for an exit } \\
\text { Diplomacy rears its reluctant head and the "truce" word } \\
\text { is suddenly everywhere as Israel's war on Gaza enters } \\
\text { its third week. Saleh Al-Naami reports from the } \\
\text { besieged Strip }\end{array}$ \\
\hline 1 & 2009, January 15 & $\begin{array}{l}\text { Abbas in limbo } \\
\text { Ramallah's silence on Israel's campaign of slaughter in } \\
\text { Gaza is turning back on Fatah with a vengeance, writes } \\
\text { Khaled Amayreh }\end{array}$ \\
\hline 1 & 2009, January 15 & $\begin{array}{l}\text { Families } \\
\text { Israel is using weapons of mass destruction to take out } \\
\text { ordinary families in Gaza, reports Saleh Al-Naami }\end{array}$ \\
\hline 1 & 2009, January 15 & $\begin{array}{l}\text { Gazan tragedy brought home } \\
\text { Some Palestinians wounded in Gaza have been taken } \\
\text { to Egypt for treatment. Nesmahar Sayed heard the } \\
\text { sound of pain }\end{array}$ \\
\hline 1 & 2009, January 15 & $\begin{array}{l}\text { Non- } \\
\text { Doaa El-Bey failed to find any sign that } \underline{\text { Israel's attack }} \\
\text { on Gaza will soon end }\end{array}$ \\
\hline 1 & 2009, January 15 & $\begin{array}{l}\text { White phosphorous but no flag } \\
\text { The Palestinians refuse to succumb to defeat in the face } \\
\text { of flagrant Israeli war crimes. Saleh Al-Naami reports } \\
\text { from Gaza }\end{array}$ \\
\hline 1 & 2009, January 22 & $\begin{array}{l}\text { Calm after the storm? } \\
\text { Who won and who lost in Israel's brutal war on Gaza, } \\
\text { and what lies ahead now? Saleh Al-Naami explores } \\
\text { possibilities }\end{array}$ \\
\hline 1 & 2009, January 22 & $\begin{array}{l}\text { 'Crime of crimes' } \\
\text { Former judge at the International Criminal Tribunal for } \\
\text { the Former Yugoslavia, Fouad Riad, tells Amira } \\
\text { Howeidy that Israel is guilty of genocide in its 22-day } \\
\text { war on Gaza }\end{array}$ \\
\hline 1 & 2009, January 22 & $\begin{array}{l}\text { Still breathing } \\
\text { The endurance of Palestinians in Gaza in the face of } \\
\text { Israel's overwhelming onslaught is humbling, } \\
\text { demanding, and should be met by our action, writes } \\
\text { Caoimhe Butterly* from Gaza City }\end{array}$ \\
\hline 1 & 2009, January 22 & $\begin{array}{l}\text { Vista of endless ruin } \\
\text { With Israel's guns temporarily silent, Gazans are seeing } \\
\text { the full scale of destruction and death Israel visited } \\
\text { upon them, writes Saleh Al-Naami }\end{array}$ \\
\hline & 2009, January 22 & $\begin{array}{l}\text { With friends like these } \\
\text { By Sherine } \\
\text { KHALED AMAYREH, the Al-Ahram Weekly } \\
\text { correspondent in the West Bank was arrested Sunday } \\
\text { evening by the Preventive Security Forces (PSF) in }\end{array}$ \\
\hline
\end{tabular}


The Discursive Representation of Social Groups through Lexical Choices in Headlines: A Critical Discourse Analysis of Western and Arab Online Reporting on Gaza War

\begin{tabular}{|l|l|}
\hline & $\begin{array}{l}\text { Hebron. He was released after two days. Amayreh, 52, } \\
\text { lives in Dura, 12 miles southwest of Hebron and has } \\
\text { worked as the Weekly correspondent since 1997, as } \\
\text { well as for a number of other media outlets. }\end{array}$ \\
\hline $\begin{array}{l}\text { *Note: Some of the articles are no longer retrievable from Al-Ahram Weekly } \\
\text { Online archives; yet they are saved on masress.com database. Masress is a } \\
\text { website that collects news from 105 Egyptian newspapers, without editing or } \\
\text { changing their original content. }\end{array}$ \\
\hline
\end{tabular}

Articles retrieved from Al Jazeera English online:

\begin{tabular}{|c|c|c|}
\hline \multicolumn{2}{|c|}{$\begin{array}{l}\text { Articles retrieved from } \\
\text { http://www.aljazeera.com/ }\end{array}$} & Al jazeera English \\
\hline No. & Date & Headline \\
\hline 1 & 2008, December 27 & $\begin{array}{l}\text { Hundreds die in Israel raid on } \\
\text { Gaza } \\
\text { Air assault targets security buildings } \\
\text { killing at least } 220 \text { people and injuring } \\
700 \text { more. }\end{array}$ \\
\hline 2 & 2008, December 28 & $\begin{array}{l}\text { Abbas blames Hamas for } \\
\text { bloodshed } \\
\text { President says attacks on Gaza could } \\
\text { have been averted if Hamas extended } \\
\text { truce. }\end{array}$ \\
\hline 3 & 2008, Dec & $\begin{array}{l}\text { Arab leaders 'to meet' on Gaza } \\
\text { Qatar has called for a summit of Arab } \\
\text { League leaders to be held in Doha next } \\
\text { Friday. }\end{array}$ \\
\hline 4 & $2008, \mathrm{Dec}$ & $\begin{array}{l}\text { Arab street angry over Gaza } \\
\text { attacks } \\
\text { Tens of thousands protest across middle } \\
\text { east over Israeli bombardment. }\end{array}$ \\
\hline 5 & 2008, December 28 & $\begin{array}{l}\text { Gaza toll nears } 300 \text { amid new } \\
\text { raids } \\
\text { UN urges end to military operations as } \\
\text { Israel gives army go ahead to call up } \\
\text { reservists. }\end{array}$ \\
\hline 6 & $2008, \mathrm{Dec}$ & $\begin{array}{l}\text { Hamas calls for third Intifada } \\
\text { Political leader of Hamas says } \\
\text { "resistance will continue through } \\
\text { suicide missions". }\end{array}$ \\
\hline 7 & 2008, December 28 & $\begin{array}{l}\text { Hezbollah fighters placed on alert } \\
\text { Leader says Israeli forces along border } \\
\text { with Lebanon may be preparing an } \\
\text { attack. }\end{array}$ \\
\hline
\end{tabular}




\begin{tabular}{|c|c|c|}
\hline \multicolumn{3}{|c|}{ Hanan Mohamed Ahmed Sharaf Eldin } \\
\hline & 2008, December 28 & $\begin{array}{l}\text { Israel resumes } \\
\text { bombardment } \\
\text { Ground offensive threatened after the } \\
\text { deadliest attack on Palestinians for } \\
\text { decades. }\end{array}$ \\
\hline 9 & 2008, December 28 & $\begin{array}{l}\text { US blames Hamas 'thugs' for } \\
\text { deaths } \\
\text { White House urges Palestinians to stop } \\
\text { rocket attacks as others condemn Israeli } \\
\text { raids. }\end{array}$ \\
\hline 1 & 2008, December 28 & $\begin{array}{l}\text { Israeli jets pound Gaza tunnels } \\
\text { Lifeline tunnels near Rafah hit on } \\
\text { second day of air attacks on Gaza. }\end{array}$ \\
\hline 1 & 2008, December 29 & $\begin{array}{l}\text { US pushes to curb Hamas } \\
\text { Move comes as UN chief calls for end } \\
\text { to civilian casualties on both sides. }\end{array}$ \\
\hline 1 & 2008, December 30 & $\begin{array}{l}\text { Israel in 'all-out war' with Hamas } \\
\text { Death toll climbs as Israeli jets bombard } \\
\text { Gaza strip for third consecutive day. }\end{array}$ \\
\hline 1 & 2008, December 31 & $\begin{array}{l}\text { Obama's Gaza silence condemned } \\
\text { Is the US president-elect "complicit" in } \\
\text { Israel's Gaza raids by remaining silent? }\end{array}$ \\
\hline 1 & 2008, December 31 & $\begin{array}{l}\text { Israel rebuffs Gaza ceasefire calls } \\
\text { Palestinian president strikes } \\
\text { conciliatory tone with Hamas as Israel } \\
\text { rejects truce plan. }\end{array}$ \\
\hline 1 & 2008, December 31 & $\begin{array}{l}\text { Israel rules out immediate truce } \\
\text { Tel Aviv rejects French ceasefire } \\
\text { proposal to allow humanitarian aid into } \\
\text { Gaza. }\end{array}$ \\
\hline 1 & 2008, December 31 & $\begin{array}{l}\text { Israeli vessel hits Gaza-bound } \\
\text { boat } \\
\text { Aid boat limps to Lebanese port after } \\
\text { being "rammed" and forced to return. }\end{array}$ \\
\hline 1 & 2008, December 31 & $\begin{array}{l}\text { Pressure builds for Gaza ceasefire } \\
\text { Israel and Hamas urged to agree } \\
\text { temporary truce as death toll nears } 400 \text {. }\end{array}$ \\
\hline 1 & 2009, January 1 & $\begin{array}{l}\text { Livni: no crisis in Gaza strip } \\
\text { Foreign minister rejects EU truce and } \\
\text { says Israel "supplying comprehensive } \\
\text { aid" to Gaza. }\end{array}$ \\
\hline & 2009, January 2 & Angry protests over Gaza offensive \\
\hline & & Demonstrations staged in several \\
\hline
\end{tabular}


The Discursive Representation of Social Groups through Lexical Choices in Headlines: A Critical Discourse Analysis of Western and Arab Online Reporting on Gaza War

\begin{tabular}{|c|c|}
\hline & countries decrying Israeli offensive. \\
\hline 2009, January 2 & $\begin{array}{l}\text { Fears grow of Gaza ground assault } \\
\text { Israeli strike kills senior Hamas figure } \\
\text { as ground forces prepare for possible } \\
\text { invasion. }\end{array}$ \\
\hline 2009, January 2 & $\begin{array}{l}\text { US 'working towards Gaza ceasefire' } \\
\text { US secretary of state condemns Hamas } \\
\text { for holding Palestinians in Gaza } \\
\text { "hostage". }\end{array}$ \\
\hline 2009, January 3 & Bush calls for pressure on Hamas \\
\hline & $\begin{array}{l}\text { US president says Palestinian faction } \\
\text { 'instigated' Israeli attacks on Gaza. }\end{array}$ \\
\hline 2009, January 3 & $\begin{array}{l}\text { Gaza mourns as strikes continue } \\
\text { Toll reaches } 428 \text { as Israel maintains } \\
\text { its aerial bombardment of the Gaza } \\
\text { Strip. }\end{array}$ \\
\hline 2009, January 3 & Israel begins Gaza ground offensive \\
\hline & $\begin{array}{l}\text { Armoured convoy and troops enter } \\
\text { Gaza Strip as Hamas vows to defeat } \\
\text { Israeli forces. }\end{array}$ \\
\hline 2009, January 3 & Israel continues Gaza assault \\
\hline & $\begin{array}{l}\text { Hamas warns Israel against ground } \\
\text { offensive as group's field commander } \\
\text { dies in bombardment. }\end{array}$ \\
\hline 2009, January 4 & Israel pushes deeper into Gaza \\
\hline & $\begin{array}{l}\text { Intensive sea and air strikes } \\
\text { accompany Israeli ground offensive on } \\
\text { the Gaza Strip. }\end{array}$ \\
\hline 2009, January 4 & Israeli ground troops enter Gaza \\
\hline & $\begin{array}{l}\text { Heavy fighting reported as Israel } \\
\text { launches its ground offensive on the } \\
\text { Gaza Strip. }\end{array}$ \\
\hline 2009, January 5 & Fighting rages in Gaza \\
\hline & $\begin{array}{l}\text { Palestinian fighters battle Israeli } \\
\text { ground forces in and around Gaza } \\
\text { City. }\end{array}$ \\
\hline 2009, January 5 & Hamas confident of Gaza victory \\
\hline & $\begin{array}{l}\text { Senior leader says "victory is coming" } \\
\text { as Israeli ground offensive splits Gaza } \\
\text { Strip. }\end{array}$ \\
\hline 2009, January 5 & Hamas 'to attend' Cairo truce talks \\
\hline & $\begin{array}{l}\text { Diplomatic efforts aimed at getting } \\
\text { ceasefire stepped up as Israeli } \\
\text { offensive continues. }\end{array}$ \\
\hline 2009, January 6 & Civilian deaths mount in Gaza war \\
\hline
\end{tabular}




\begin{tabular}{|c|c|}
\hline \multicolumn{2}{|c|}{ Hanan Mohamed Ahmed Sharaf Eldin } \\
\hline & $\begin{array}{l}\text { Israeli artillery hits hospital as } \\
\text { Palestinian death toll rises to at least } \\
548 \text {. }\end{array}$ \\
\hline \multirow[t]{2}{*}{ 2009, January 6} & Israel rejects truce proposal \\
\hline & $\begin{array}{l}\text { EU ceasefire proposal spurned as US } \\
\text { blames Hamas for fighting and } \\
\text { humanitarian situation. }\end{array}$ \\
\hline \multirow[t]{2}{*}{ 2009, January 6} & Israel's 'colonial tactics' decried \\
\hline & $\begin{array}{l}\text { Analyst says Hamas rockets are not } \\
\text { the cause but a response to the } \\
\text { occupation. }\end{array}$ \\
\hline \multirow[t]{2}{*}{2009, January 7} & Abbas urges action on Gaza \\
\hline & $\begin{array}{l}\text { Palestinian leader says diplomatic } \\
\text { delays would lead only to further } \\
\text { tragedy in Gaza. }\end{array}$ \\
\hline \multirow[t]{2}{*}{ 2009, January 7} & Israel kills dozens at Gaza school \\
\hline & $\begin{array}{l}\text { Shells hit UN school sheltering } \\
\text { hundreds of civilians in Jabaliya } \\
\text { refugee camp. }\end{array}$ \\
\hline \multirow[t]{2}{*}{ 2009, January 7} & Scores killed as Gaza UN school hit \\
\hline & $\begin{array}{l}\text { Israeli shells hit UN school sheltering } \\
\text { hundreds of civilians in Jabalya } \\
\text { refugee camp. }\end{array}$ \\
\hline \multirow[t]{2}{*}{ 2009, January 8} & Israel fires on UN Gaza convoy \\
\hline & $\begin{array}{l}\text { Lorries come under fire while } \\
\text { travelling to Erez crossing to pick up } \\
\text { aid for distribution. }\end{array}$ \\
\hline \multirow[t]{2}{*}{2009, January 8} & Israel resumes deadly Gaza attacks \\
\hline & $\begin{array}{l}\text { Air raids intensify as Israel moves to } \\
\text { broaden offensive after three-hour } \\
\text { lull. }\end{array}$ \\
\hline \multirow[t]{2}{*}{ 2009, January 8} & Israeli bombardment pounds Gaza \\
\hline & $\begin{array}{l}\text { Tunnels and homes around Rafah } \\
\text { come under intense attack after Israeli } \\
\text { warning. }\end{array}$ \\
\hline \multirow[t]{2}{*}{ 2009, January 10} & Gazans: 'We face a dark destiny' \\
\hline & $\begin{array}{l}\text { Palestinians from the Gaza Strip } \\
\text { explain how Israel's ground offensive } \\
\text { is affecting them. }\end{array}$ \\
\hline \multirow[t]{2}{*}{ 2009, January 10} & Israel 'shelled Gaza civilians' \\
\hline & $\begin{array}{l}\text { Palestinians were moved into a house } \\
\text { which was later hit by Israeli fire, UN } \\
\text { says. }\end{array}$ \\
\hline \multirow[t]{2}{*}{ 2009, January 11} & Death toll in Gaza exceeds 850 \\
\hline & Israeli assault enters third week with \\
\hline
\end{tabular}


The Discursive Representation of Social Groups through Lexical Choices in Headlines: A

Critical Discourse Analysis of Western and Arab Online Reporting on Gaza War

\begin{tabular}{|c|c|}
\hline & $\begin{array}{l}\text { military warning it will "escalate" the } \\
\text { conflict. }\end{array}$ \\
\hline 2009, January 12 & Gazans fear Israel using phosphorus \\
\hline & $\begin{array}{l}\text { Patients' injuries consistent with the } \\
\text { use of controversial chemical, doctors } \\
\text { say. }\end{array}$ \\
\hline 2009, January 12 & Israeli troops battle Gaza fighters \\
\hline & $\begin{array}{l}\text { Intense clashes reported on the edge of } \\
\text { Gaza City as offensive continues for } \\
17 \text { th day. }\end{array}$ \\
\hline 2009, January 16 & $\begin{array}{l}\text { Children 'paying price of Gaza war' } \\
\text { More than } 300 \text { children have been } \\
\text { killed in Israel's continuing assault, } \\
\text { UN says. }\end{array}$ \\
\hline 2009, January 16 & Gaza hospitals and UN warehouse hit \\
\hline & $\begin{array}{l}\text { Offensive enters 21st day after } \\
\text { millions of dollars in food and } \\
\text { medicine go up in flames. }\end{array}$ \\
\hline 2009, January 16 & Israeli missiles kill Hamas leader \\
\hline & $\begin{array}{l}\text { Hamas's interior minister was killed in } \\
\text { an Israeli air raid on his brother's } \\
\text { house. }\end{array}$ \\
\hline 2009, January 16 & Relative calm descends on Gaza \\
\hline & $\begin{array}{l}\text { Bodies are pulled from the rubble as } \\
\text { Israel says it has hit } 40 \text { targets on } \\
\text { Friday. }\end{array}$ \\
\hline 2009, January 17 & Israel shells UN school in Gaza \\
\hline & $\begin{array}{l}\text { War rages for } 22 \mathrm{nd} \text { day amid } \\
\text { speculation of imminent Israeli } \\
\text { 'unilateral ceasefire'. }\end{array}$ \\
\hline
\end{tabular}

Articles retrieved from CNN:

\begin{tabular}{|l|l|l|}
\hline \multicolumn{2}{|l|}{ Articles retrieved from CNN: http://edition.cnn.com/ } \\
\hline No. & Date & Headline \\
\hline & 2008, December 28 & $\begin{array}{l}\text { Gaza humanitarian plight 'disastrous,' } \\
\text { U.N. official says }\end{array}$ \\
\hline & 2008, December 28 & $\begin{array}{l}\text { Hundreds dead, injured in Gaza as } \\
\text { Israeli airstrikes continue }\end{array}$ \\
\hline & 2008, December 29 & $\begin{array}{l}\text { Aid reaching Gaza, but U.N. says it's } \\
\text { not enough }\end{array}$ \\
\hline & 2008, December 29 & Israeli airstrikes in Gaza enter third day \\
\hline & 2008, December 30 & $\begin{array}{l}\text { Sources: Gaza death toll from Israeli } \\
\text { offensive exceeds 375 }\end{array}$ \\
\hline
\end{tabular}




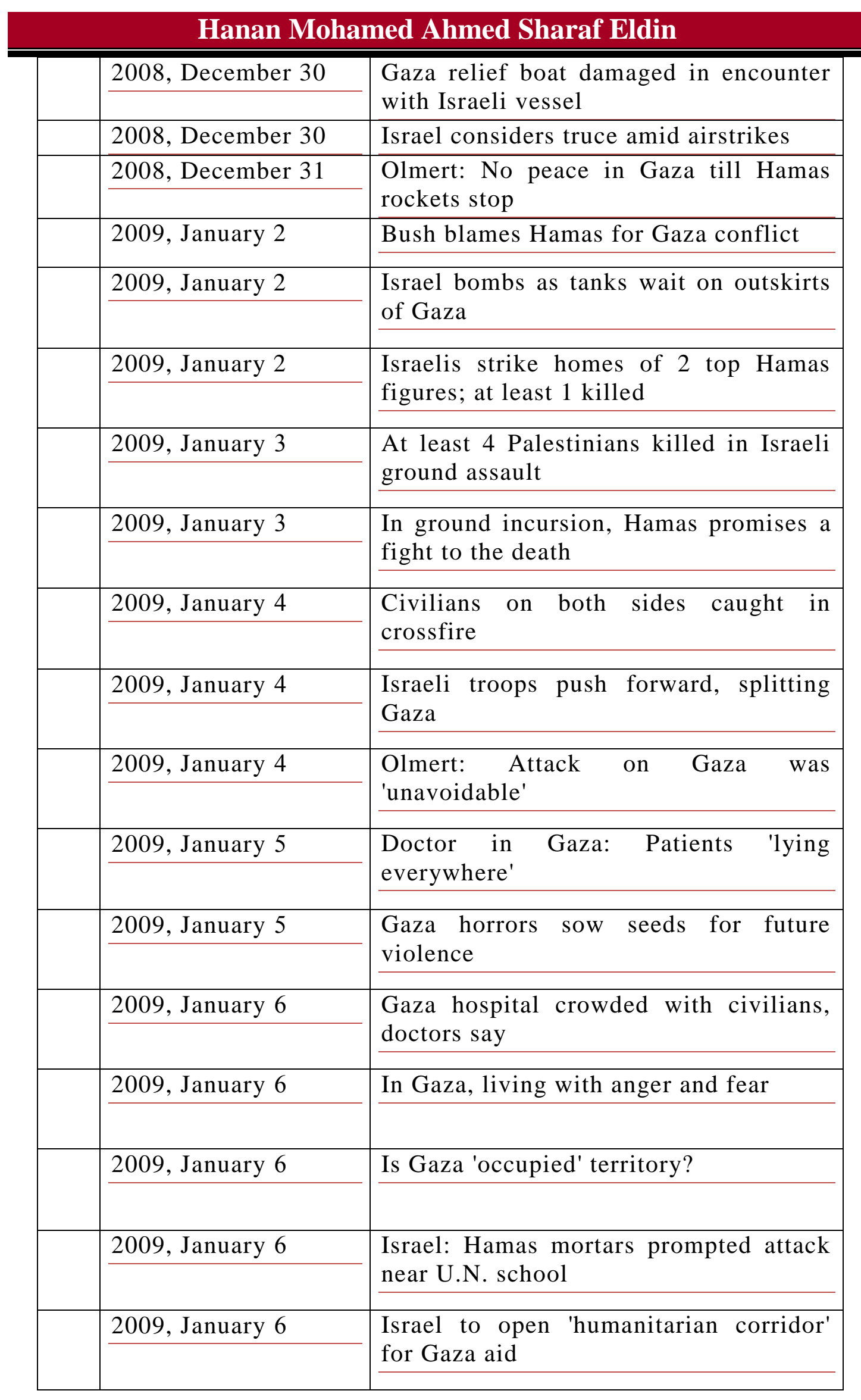


The Discursive Representation of Social Groups through Lexical Choices in Headlines: A Critical Discourse Analysis of Western and Arab Online Reporting on Gaza War

\begin{tabular}{|c|c|}
\hline 2009, January 9 & $\begin{array}{l}\text { Israel, Hamas brush off U.N. cease-fire } \\
\text { resolution }\end{array}$ \\
\hline 2009, January 9 & $\begin{array}{l}\text { Israel kills } 30 \text { civilians at shelter, } \\
\text { witnesses tell U.N. }\end{array}$ \\
\hline 2009, January 11 & $\begin{array}{l}\text { Israelis, Hamas clash near Gaza City, } \\
\text { witnesses say }\end{array}$ \\
\hline 2009, January 12 & $\begin{array}{l}\text { Group accuses Israel of firing white } \\
\text { phosphorus into Gaza }\end{array}$ \\
\hline 2009, January 12 & $\begin{array}{l}\text { Israel tightens grip on Gaza City; } \\
\text { Hamas stays defiant }\end{array}$ \\
\hline 2009, January 14 & Israel explains Gaza media restrictions \\
\hline 2009, January 16 & $\begin{array}{l}\text { Israel, U.S. target Hamas arms } \\
\text { smuggling }\end{array}$ \\
\hline 2009, January 16 & $\begin{array}{l}\text { UK Jewish lawmaker: Israeli forces } \\
\text { acting like Nazis }\end{array}$ \\
\hline 2009, January 17 & $\begin{array}{l}\text { Israel declares unilateral cease-fire in } \\
\text { Gaza }\end{array}$ \\
\hline 2009, January 17 & $\begin{array}{l}\text { Israelis edging closer to cease-fire } \\
\text { agreement in Gaza }\end{array}$ \\
\hline 2009, January 18 & $\begin{array}{l}\text { Hamas, Israel set independent cease- } \\
\text { fires }\end{array}$ \\
\hline 2009, January 19 & $\begin{array}{l}\text { Palestinians: } 1,300 \text { killed, } 22,000 \\
\text { buildings destroyed in Gaza }\end{array}$ \\
\hline 2009, January 19 & 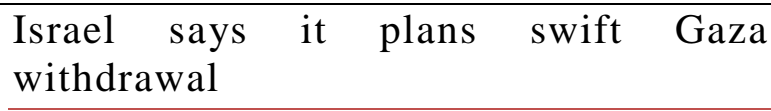 \\
\hline 2009, January 21 & Israeli troops complete Gaza withdrawal \\
\hline
\end{tabular}

Articles retrieved from NYT:

\begin{tabular}{|l|l|l|l|}
\hline \multicolumn{6}{|l|}{ Articles retrieved from NYT: http://www.nytimes.com/ } \\
\hline No. & Date & Headline \\
\hline & $2008, \quad$ December & $\begin{array}{l}\text { Foreign Minister of Israel says Hamas } \\
\text { should be condemned }\end{array}$ \\
\hline & 28 & & \\
28 & & & \\
\hline
\end{tabular}




\section{Hanan Mohamed Ahmed Sharaf Eldin}

\begin{tabular}{|c|c|}
\hline $\begin{array}{l}2008, \quad \text { December } \\
29\end{array}$ & $\begin{array}{l}\text { A captured Israeli soldier figures in } \\
\text { military assessments and political calculus }\end{array}$ \\
\hline $\begin{array}{l}2008, \quad \text { December } \\
29\end{array}$ & $\begin{array}{l}\text { Israeli troops mass along border; Arab } \\
\text { anger rises }\end{array}$ \\
\hline $\begin{array}{l}2008, \quad \text { December } \\
29\end{array}$ & $\begin{array}{l}\text { No early end seen to 'All-Out War' on } \\
\text { Hamas in } \\
\text { Gaza } \\
\text { Israeli aircraft continue raids on Gaza; } \\
\text { Arab anger rises }\end{array}$ \\
\hline $\begin{array}{l}2008, \quad \text { December } \\
30\end{array}$ & $\begin{array}{l}\text { Amid a buildup of its forces, Israel ponders } \\
\text { a cease-fire }\end{array}$ \\
\hline $\begin{array}{ll}2008, & \text { December } \\
30 & \\
\end{array}$ & Despite strikes, Israelis vow to soldier on \\
\hline $\begin{array}{l}2008, \quad \text { December } \\
31\end{array}$ & In dense Gaza, civilians suffer \\
\hline $\begin{array}{ll}2008, & \text { December } \\
31\end{array}$ & Israel rejects Gaza cease-fire, but offers aid \\
\hline $\begin{array}{l}2008, \quad \text { December } \\
31\end{array}$ & $\begin{array}{l}\text { Striking deep into Israel, Hamas employs } \\
\text { an upgraded rocket arsenal }\end{array}$ \\
\hline 2009, January 1 & $\begin{array}{l}\text { In a broadening offensive, Israel steps up } \\
\text { diplomacy }\end{array}$ \\
\hline 2009, January 2 & Israel lets some foreigners leave Gaza \\
\hline 2009 , January 3 & Israeli troops launch attack on Gaza \\
\hline 2009, January 3 & Is the real target Hamas rule? \\
\hline 2009, January 4 & Gaza hospital fills up, mainly with civilians \\
\hline 2009 , January 5 & $\begin{array}{l}\text { In Fatah-governed West Bank, solidarity } \\
\text { with Hamas }\end{array}$ \\
\hline 2009 , January 5 & $\begin{array}{l}\begin{array}{l}\text { Israel deepens Gaza incursion as toll } \\
\text { mounts }\end{array} \\
\end{array}$ \\
\hline 2009, January 5 & Warnings not enough for Gaza families \\
\hline 2009, January 6 & Israel puts media clamp on Gaza \\
\hline 2009, January 6 & Israeli shells kill 40 at Gaza U.N. school \\
\hline 2009, January 6 & $\begin{array}{l}\text { Rice heads to U.N. for talks on Gaza cease- } \\
\text { fire }\end{array}$ \\
\hline 2009, January 7 & Grief and rage at stricken Gaza school \\
\hline 2009, January 7 & $\begin{array}{l}\text { Israel resumes attack after pause for aid } \\
\text { delivery }\end{array}$ \\
\hline 2009, January 7 & $\begin{array}{l}\text { Israelis honor fallen soldiers, while seeing } \\
\text { the Gaza campaign as justified }\end{array}$ \\
\hline 2009, January 8 & Fighter sees his paradise in Gaza's pain \\
\hline 2009, January 8 & $\begin{array}{l}\text { Israel condemns Vatican's 'concentration } \\
\text { camp' remarks }\end{array}$ \\
\hline 2009, January 8 & Israel faces mounting outcry on Gaza war \\
\hline 2009, January 8 & $\begin{array}{l}\text { Red Cross accuses Israel of neglecting } \\
\text { Gaza wounded }\end{array}$ \\
\hline 2009, January 9 & 30 Confirmed dead in shelling of Gaza \\
\hline
\end{tabular}


The Discursive Representation of Social Groups through Lexical Choices in Headlines: A

Critical Discourse Analysis of Western and Arab Online Reporting on Gaza War

\begin{tabular}{|l|l|l|}
\hline & & family \\
\hline & 2009, January 9 & For Arab clan, days of agony in a cross-fire \\
\hline & 2009, January 10 & A Gaza war full of traps and trickery \\
\hline & 2009, January 12 & $\begin{array}{l}\text { As talks falter, Israel warns of more } \\
\text { extensive attacks }\end{array}$ \\
\hline & U.N. warns of refugee crisis in Gaza strip \\
\hline & 2009, January 13 & $\begin{array}{l}\text { Hamas fighters display mix of swagger and } \\
\text { fear }\end{array}$ \\
\hline & $\begin{array}{l}\text { Israel says Hamas is damaged, not } \\
\text { destroyed }\end{array}$ \\
\hline & 2009, January 14 & $\begin{array}{l}\text { Egypt cites progress toward truce as Gaza } \\
\text { toll exceeds 1,000 }\end{array}$ \\
\hline War on Hamas saps Palestinian leaders \\
\hline 2009, January 16 15 & $\begin{array}{l}\text { Israel shells U.N. site in Gaza, drawing } \\
\text { fresh condemnation }\end{array}$ \\
\hline 2009, January 17 & $\begin{array}{l}\text { Gaeli cabinet appears ready to declare a } \\
\text { Gaza cease-fire } \\
\text { daughters to Israeli fire and asks why }\end{array}$ \\
\hline & 2009, January 17 & $\begin{array}{l}\text { In homes and on streets, a war that feels } \\
\text { deadlier }\end{array}$ \\
\hline & $\begin{array}{l}\text { Israel declares cease-fire; Hamas says it } \\
\text { will fight on }\end{array}$ \\
\hline
\end{tabular}

